\title{
Phosphorus Influence on Plant Tissue Nitrogen Contents and Yield Attributes of Finger Millet Varieties in Semi-arid Region of Kenya
}

\author{
Wekha N. Wafula ${ }^{1,2^{\star}}$, Nicholas K. Korir ${ }^{1}$, Henry F. Ojulong ${ }^{2}$, Moses Siambi ${ }^{2}$ \\ and Joseph P. Gweyi-Onyango ${ }^{1}$ \\ ${ }^{1}$ Department of Agricultural Science and Technology, Kenyatta University, P.O.Box 43844-00100, \\ Nairobi, Kenya. \\ ${ }^{2}$ International Crops Research Institute for the Semi-Arid Tropics (ICRISAT), P.O.Box 39063-00623, \\ Nairobi, Kenya. \\ Authors' contributions \\ This work was carried out in collaboration between all authors. Author WNW designed the study, \\ wrote the protocol and wrote the first draft of the manuscript. Authors HFO, MS and JPGO reviewed \\ the study design and all drafts of the manuscript. Author NKK managed the analyses of the study. \\ Author WNW managed the literature searches. All authors read and approved the final manuscript.
}

Article Information

DOI: $10.9734 /$ IJPSS/2016/29901

Editor(s):

(1) Davide Neri, Polytechnic University of Marche - Via Brecce White, Ancona, Italy. (2) Fatemeh Nejatzadeh, Department of Horticulture, Faculty of Agriculture, Khoy Branch, Islamic Azad University, Iran.

Reviewers:

(1) Abdulmajeed Hamza, University of Ibadan, Ibadan, Nigeria. (2) Anélia Marais, Western Cape Department of Agriculture, South Africa. (3) Nkeki Kamai, University of Maiduguri, Nigeria. Complete Peer review History: http://www.sciencedomain.org/review-history/16885

\begin{abstract}
The experiment was conducted with the aim of evaluating the effect of differential levels of $\mathrm{P}$ on finger millet accumulation of $\mathrm{N}$ and yield components. On-station experiments were conducted at the KALRO-Kiboko crops research station in Makueni County during the short and long rains of 2014 and 2015 respectively. There were 4 levels of $P\left(0,12.5,25\right.$ and $\left.37.5 \mathrm{~kg} \mathrm{ha}^{-1} \mathrm{P}_{2} \mathrm{O}_{5}\right)$ and three varieties (U-15, P-224 and Ekalakala). Ekalakala was the local check while $0 \mathrm{~kg} / \mathrm{ha} \mathrm{P}_{2} \mathrm{O}_{5}$ was the control. The trial was laid out in a randomized complete block design and fitted in factorial arrangement with three replicates given a total of 36 plots. Soil sampling was at a depth of $0-30 \mathrm{~cm}$ on all the plots and analytical results showed moderately available $\mathrm{P}$ but very low $\mathrm{N}$, organic carbon
\end{abstract}


and zinc. Significant differences $(P=.05)$ were observed between the phosphate levels on the nitrogen contents in plant parts with the control showing the lowest $\mathrm{N}$ accumulation of $4.95 \%$ and $4.90 \%$ for the short and long rains respectively while the $25 \mathrm{~kg} \mathrm{ha}^{-1} \mathrm{P}_{2} \mathrm{O}_{5}$ rate had the highest with $5.66 \%$ in the short rains and $5.14 \%$ in the long rains. The stem contained the highest nitrogen content while the roots had the lowest. Phosphate rates did not have significant influence on the yield components except the finger width while the varieties varied significantly $(P=.05)$ on the productive tillers, panicle number, grains per spikelet and the harvest index. Variety U-15 had the highest yield for both seasons with a maximum of $3410 \mathrm{~kg} \mathrm{ha}^{-1}$ for the short rains. The newly released variety $(\mathrm{U}-15)$ responded well to moderate $\mathrm{P}$ supplemented at $25 \mathrm{~kg} \mathrm{ha}^{-1} \mathrm{P}_{2} \mathrm{O}_{5}$ thus can efficiently utilize $\mathrm{N}$ in soils with low $\mathrm{N}$ like in Makueni and is highly recommended. The optimal $\mathrm{P}$ for the yield and $\mathrm{N}$ accumulation was $25 \mathrm{~kg} \mathrm{ha}^{-1} \mathrm{P}_{2} \mathrm{O}_{5}$ and beyond this point the $\mathrm{P}$ would not be translated to profitable yield but a loss to the farmer in the short run.

Keywords: Finger millet; available $P$; $N$ accumulation; grains per spikelet.

\section{INTRODUCTION}

Finger millet (Eleusine coracana) is the most important small millet grown in eastern and southern Africa and it serves as a subsistence and food security crop that is especially important for its nutrition and resilience to harsh weather conditions. Of all major cereals, this crop is one of the most nutritious [1] especially in calcium. It is a food crop in traditionally low input cereal-based farming systems in Africa, and is of particular importance in upland areas of Eastern Africa. While developing countries in Asia still produce the majority of the world's millets, Africa is becoming the hub of production [2]. In Kenya, the crop is mainly produced in the part of the country west of the Rift Valley and it is cultivated

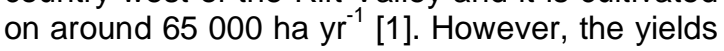
of finger millet on farmers' fields are generally low, just about $15-16 \%$ of their potential maximum in Kenya [3]. Soil infertility is one of the major constraints to finger millet production throughout much of the Sub-Saharan Africa.

An understanding of the internal and external $P$ efficiencies of modern finger millet varieties is very important in selection of varieties adaptable to $\mathrm{P}$ deficient and moderate $\mathrm{P}$ conditions. Phosphorus deficiency has been identified as one of the most limiting soil nutrient after nitrogen due to soil erosion, continuous cultivation and fast reversion of soluble $\mathrm{P}$ where $\mathrm{P}$ fertilization is of fundamental importance in replenishing, enhancing and maintaining soil fertility [4]. Achievement of higher efficacy and efficiency of $P$ mineral fertilization is possible through searching for and improving the methods of assessment of plant nutritional status as well as aiming at optimization of fertilizer use. Knowledge on factual needs of plants concerning balancing of mineral nutrients and utilization efficiency is an important aspect of reducing agricultural negative effects on environment through improper $\mathrm{P}$ fertilization.

Nutrient limitation of ecosystems is typically determined by fertilization experiments, with increased biomass or growth rates taken as evidence of limitation [5,6]. A less direct index of nutrient limitation is foliar nutrient concentration, which is predicted to increase in response to addition of the limiting nutrient, although the positive relationship between biomass and foliar nutrients is not necessarily a linear one. This index is reasonable given that foliar nutrient concentrations (expressed either as $\mathrm{N}$ concentration, $\mathrm{P}$ concentration, or a ratio of $\mathrm{N}$-toP) reflect soil nutrient concentrations $[7,8])$. Foliar $\mathrm{N}$ and $\mathrm{P}$ concentrations also relate to the functioning of plants, as comparisons across agro-ecologies have shown that they are correlated with physiological traits such as photosynthesis and dark respiration, and leaf properties that affect resource capture such as specific leaf area and leaf lifespan [9].

Finger millet has high genetic diversity [10]. All finger millet varieties do not respond to nutrients in the same manner. Genotypic variability among different finger millet cultivars has been reported for responsiveness to N and P [11]. Gupta et al. [12] evaluated the $\mathrm{N}$ use efficiency (ratio of grain yield to $N$ supply) and $N$ utilization efficiency (ratio of grain yield to total $\mathrm{N}$ uptake) of three finger millet genotypes under different $\mathrm{N}$ inputs and found that there was genotypic variability among the finger millet genotypes' responses to different $\mathrm{N}$ inputs, wherein some varieties were highly responsive to $\mathrm{N}$. Therefore, the understanding of the existence in genetic variability in finger millet genotypic response to nutrients prompted the need to study yield and $\mathrm{N}$ 
accumulation responses to $\mathrm{P}$ among different varieties in marginal Kiboko, of lower area in Eastern Kenya.

\section{MATERIALS AND METHODS}

\subsection{Site Description}

The experiment was conducted during the 2014 short and 2015 long rains season at the International Crops Research Institute for the Semi-Arid Tropics (ICRISAT) and Kenya Agricultural and Livestock Research Organization (KALRO)-Kiboko Crops Research Station where the previous crop planted was pigeon pea. The station is in Kiboko Location, Makueni County. It lies within longitudes 37\%38" East, latitudes 291" South and at an elevation of $975 \mathrm{~m}$ above sea level. The soils are classified as Acri-Rhodic Ferrassols [13] composed of sand $(43.08 \%)$, silt $(33.91 \%)$ and clay $(23.01 \%)$ with an average $\mathrm{pH}$ unit of 8.9. Mean available $\mathrm{P}$ was found to be moderate while nitrogen, organic carbon and zinc were extremely low as shown in Table 1. The station received a total of 441 and $286.3 \mathrm{~mm}$ rainfall during the short and long rain seasons respectively. The mean maximum and minimum temperature for the short and long rains were $31.8^{\circ} \mathrm{C}$ and $17.9^{\circ} \mathrm{C}$, and $29.7^{\circ} \mathrm{C}$ and $15.7^{\circ} \mathrm{C}$ respectively with mean precipitation of $83.3 \%$ and $85 \%$ potential evaporation during the short and long rains respectively.

\section{Table 1. Physiochemical properties of experimental site in Kiboko}

\begin{tabular}{|c|c|c|}
\hline \multicolumn{3}{|l|}{ Physical properties } \\
\hline Sand \% & \multicolumn{2}{|c|}{43.08} \\
\hline Silt \% & \multicolumn{2}{|c|}{33.91} \\
\hline Clay \% & \multicolumn{2}{|c|}{23.01} \\
\hline $\begin{array}{l}\text { Chemical } \\
\text { properties }\end{array}$ & Short rains & Long rains \\
\hline Soil pH & 8.55 & 9.25 \\
\hline Available N \% & 0.03 & 0.03 \\
\hline Organic carbon \% & 0.24 & 0.26 \\
\hline Extractable P ppm & 13.25 & 15.5 \\
\hline Potassium me \% & 0.49 & 1.53 \\
\hline Calcium me \% & 4.37 & 10.7 \\
\hline Magnesium me \% & 2.95 & 3.26 \\
\hline Manganese me \% & 0.26 & 0.14 \\
\hline Copper ppm & 2.38 & 2.51 \\
\hline Iron ppm & 25.2 & 44.2 \\
\hline Zinc ppm & 1.45 & 2.86 \\
\hline Sodium me \% & 0.47 & 1.05 \\
\hline $\begin{array}{l}\text { Electrical } \\
\text { conductivity } \mathrm{mS} / \mathrm{cm}\end{array}$ & 0.47 & 0.27 \\
\hline
\end{tabular}

\subsection{Experimental Design, Treatments and Data Collection}

The experiment was laid out in a Randomized Complete Block Design in a factorial arrangement and replicated three times. That is, $4 \mathrm{P}$ rates $\left(0,12.5,25\right.$ and $\left.37.5 \mathrm{~kg} \mathrm{ha}^{-1} \mathrm{P}_{2} \mathrm{O}_{5}\right) \times 3$ varieties (U-15, P-224 and Ekalakala) $\times 3$ replicates (total of 36 treatments). Where Ekalakala was the local check and $0 \mathrm{~kg} \mathrm{ha}^{-1} \mathrm{P}_{2} \mathrm{O}_{5}$ was the absolute control. Phosphate fertilizer was measured according to the treatment and divided per row and hand applied as whole during planting as triple superphosphate. Seeds were drilled in the rows and thinned four weeks after planting to a spacing of $10 \mathrm{~cm}$ between plants and $50 \mathrm{~cm}$ between rows giving a total of 205 plants per plot. The experimental units measured $4 \mathrm{~m}$ long and $2 \mathrm{~m}$ wide with a $2 \mathrm{~m}$ pathway which also separated the plots. Recommended cultural practices were applied throughout the crop growth as per crop demands. The crop was harvested at physiological maturity when $90 \%$ browning of the heads was observed. The three middle rows were harvested on a net area of $3 \mathrm{~m}^{2}$. Data was collected on the number of productive tillers, finger width, finger length, grains per spikelet, number of panicles harvested and the grain yield according to the IBPGR [14]. The harvest index was calculated as ratio of the grain to biological yield.

\subsection{Soil Samples and Plant Tissue Analysis}

Soil samples $(500 \mathrm{~g})$ were collected from every experimental plot at a depth of $0-30 \mathrm{~cm}$ using a soil auger then air-dried in a well-ventilated room for 3 days. The samples were then ground and passed through a 2-mm sieve to obtain $50 \mathrm{~g}$ uniform samples from each plot for analysis and storage. The soil $\mathrm{pH}$ was determined electrometrically in water as outlined by Okalebo et al. [15]. Plant samples from five plants from each experimental unit were collected and separated into roots, stem, leaves and grain. The samples were weighed and oven-dried to a constant weight at $70^{\circ} \mathrm{C}$ for 48 hours. The dried plant material was ground using a Crompton Willey mill and passed through a 2-mm sieve to a uniform mass of $8 \mathrm{~g}$ for analysis. Soil and plant tissue nitrogen was determined the by Kjeldahl method while organic carbon content was determined using modified Walkley and Black wet oxidation [16]. The analysis of $\mathrm{N}$ and organic 
carbon were done as described by Ryan et al. [16]. Extractable potassium was determined by flame photometer [8] whereby a neutral salt solution replaced cations present on the soil exchange complex. Extractable soil nutrients ( $\mathrm{Ca}, \mathrm{Mg}, \mathrm{Mn}, \mathrm{Cu}, \mathrm{Fe}, \mathrm{Zn}$, and $\mathrm{Na}$ ) were determined by the Diethylenetriamine Pentaacetic Acid (DTPA) method then measured with an AAS [17]. Determination of $P$ involved digestion of soil sample with a strong acid and the dissolution of all insoluble inorganic minerals and organic $P$ forms which followed the procedure described by Olsen and Sommers [18]. For the electrical conductivity, a $5 \mathrm{~g}$ sample of soil was placed in a $100 \mathrm{ml}$ disposable plastic cup; $50 \mathrm{ml}$ of deionized water was added. The slurry was shaken on a reciprocating shaker for 45 minutes, and then filtered. Electrical conductivity of the filtrate was then read with a conductivity bridge.

\subsection{Data Analysis}

Data collected was compiled, cleaned and tabulated for statistical analyses. Analysis of variance (ANOVA) was performed using GenStat statistical software version 15.1. Where a significant F-test was observed, the means were separated using Fischer's protected LSD test at $5 \%$ probability level.

\section{RESULTS AND DISCUSSION}

\subsection{Nitrogen Accumulation}

Phosphorus application had significant $(P=.05)$ influence on the nitrogen contents of finger millet. The $25 \mathrm{~kg} \mathrm{ha}^{-1} \mathrm{P}_{2} \mathrm{O}_{5}$ rate showed the highest total accumulation of nitrogen of $5.66 \%$ during the short rains and $5.49 \%$ during the long rains. The control had the lowest nitrogen content in the plant for both seasons (Table 2). The stem contained the highest nitrogen where all the treatments with phosphorus had higher $\mathrm{N}$ contents compared to the control during the short rains season. There was no clear trend in accumulation of $\mathrm{N}$ in stems in response to $\mathrm{P}$ treatments. The $25 \mathrm{~kg} \mathrm{ha}^{-1} \mathrm{P}_{2} \mathrm{O}_{5}$ rate had the highest nitrogen accumulation in the leaves and grains of the crop for both seasons with the control having the lowest except during the short rains on the leaves where the highest rate had the least. Nitrogen contents were enhanced due to the added $\mathrm{P}$ which resulted in profuse root development and shoot growth that in turn activated greater absorption of nitrogen from the soil. These results are in conformity with earlier reports [19] in cluster beans. It has been reported that fragile lands such as those in Makueni usually support cropping systems with lower nitrogen contents that also use water less efficiently leading to poor crop yields. It has been reported that as phosphorus rates increase towards the optimum, crop productivity increases but at a decreasing rate, the nitrogen contents typically declines [20]. On the other hand, the roots showed the lowest nitrogen accumulation with the control having the highest during the long rains while no significant differences at $P=.05$ were observed between the $P$ treatments in the short rains. This low accumulation of $\mathrm{N}$ in the roots might be due to the switching mechanism of the crop to partition $\mathrm{N}$ to the reproductive parts at the expense of vegetative ones especially under low soil $\mathrm{N}$ conditions. Varietal differences were observed on the nitrogen accumulation in both seasons where U15 had the highest in all the plant parts.

These genotypic variations could be due to the efficiency in acquisition of $\mathrm{P}$ and $\mathrm{N}$ from the rhizosphere, nitrogen use efficiency and phosphorus use efficiency as well as the internal mobilization of $N$ in all parts of plant. Such variations could be explained mainly by the diversity of the finger millet genotypes which is highly influenced by the environmental conditions [21]. Also, organic compounds secreted by the different varietal roots stimulated microbial activity in the rhizosphere, which might also influenced the $P$ availability [22] which is related to $\mathrm{N}$ uptake since it is the source of ATP. Phosphorus and Nitrogen acquisition plays an important role for crop adaptation to low $\mathrm{P}$ and $\mathrm{N}$ soils [22] and a higher internal $P$ and $N$ use efficiency could help to limit soil nutrient mining [23], especially in low-input farming conditions and this has been exhibited by varieties like $\mathrm{U}-15$.

A quadratic trendline (Fig. 1) revealed that the yield reached the peak (optimal) point with $25 \mathrm{~kg}$ $\mathrm{ha}^{-1} \mathrm{P}_{2} \mathrm{O}_{5}$. Beyond this point, there is likelihood of luxury consumption, which may have economic implication to a farmer. Accumulation of nitrogen by the plants was not linear, but rather polynomial and after about $25 \mathrm{~kg}$ of $\mathrm{P}$ per hectare for both seasons (Fig. 1) the nitrogen contents started to descent. Previous work by Mohidin et al. [24] reported peak yield and accumulation on nutrients at $90 \mathrm{mg} \mathrm{L}^{-1}$ as opposed to $120 \mathrm{mg} \mathrm{L}^{-1}$ with yield reducing at 120 $\mathrm{mL}^{-1}$. Depending the type of soil, $\mathrm{P}$ beyond optimal level can have a negative interaction with micronutrients such as $\mathrm{Mn}$ and $\mathrm{Zn}$ as previously 
reported [25]. Other findings [26] working with different onion varieties and different rates of $\mathrm{N}$ showed concurring results to current work. The results of the authors showed $R^{2}$ values of between 0.82-0.91 amongst varieties. Understanding optimal nutrient requirements is important particularly in regards to maintaining safe environment.

The control showed the lowest $\mathrm{N}$ because phosphorus deficiency restricts activity of meristematic sink of plants and leads to a demand for assimilates in growth that are responsible for reduction of source activity and partitioning of photo-assimilates [27].

\subsection{Yield Attributes}

Phosphate rates showed significant differences $(P=.05)$ on the finger widths with the $25 \mathrm{~kg} \mathrm{ha}^{-1}$ $\mathrm{P}_{2} \mathrm{O}_{5}$ rate having the widest spikes for both seasons as shown in Fig. 2. The finger length, harvest indices, threshability, number of harvested panicles and productive tillers were not responsive to applied $\mathrm{P}$ and were similar to the control. This was probably due to the availability of $P$ above the critical value of $10 \mathrm{ppm}$ in the study soil and therefore the additional $P$ through phosphate fertilizer did not lead to significant differences.

Table 2. Effect of phosphate rates and varieties on $\mathbf{N} \%$ concentrations in finger millet plant parts in Kiboko

\begin{tabular}{|c|c|c|c|c|c|c|c|c|c|c|}
\hline \multirow{2}{*}{$\begin{array}{l}\mathrm{P}_{2} \mathrm{O}_{5} \text { rates } \\
\left(\mathrm{kg} \mathrm{ha}^{-1}\right)\end{array}$} & \multicolumn{5}{|c|}{ Short rains } & \multicolumn{5}{|c|}{ Long rains } \\
\hline & $\begin{array}{l}\text { Root } \\
\text { N\% }\end{array}$ & $\begin{array}{l}\text { Stem } \\
\text { N\% }\end{array}$ & $\begin{array}{l}\text { Leaf } \\
\mathrm{N} \%\end{array}$ & $\begin{array}{l}\text { Grain } \\
\%\end{array}$ & $\begin{array}{l}\text { Total N } \\
\% \\
\end{array}$ & $\begin{array}{l}\text { Root } \\
\text { N\% } \\
\end{array}$ & $\begin{array}{l}\text { Stem } \\
\mathrm{N} \%\end{array}$ & $\begin{array}{l}\text { Leaf } \\
\mathrm{N} \% \\
\end{array}$ & $\begin{array}{l}\text { Grain } \\
\%\end{array}$ & $\begin{array}{l}\text { Total N } \\
\%\end{array}$ \\
\hline Control & $0.71^{a}$ & $1.53^{b}$ & $1.41^{b}$ & $1.30^{\mathrm{d}}$ & $4.95^{b}$ & $1.17^{\mathrm{a}}$ & $1.28^{c}$ & $1.17^{\mathrm{c}}$ & $1.17^{\mathrm{C}}$ & $4.79^{c}$ \\
\hline 12.5 & $0.71^{a}$ & $1.65^{\mathrm{a}}$ & $1.41^{b}$ & $1.41^{c}$ & $5.18^{b}$ & $1.05^{b}$ & $1.17^{d}$ & $1.40^{\mathrm{a}}$ & $1.28^{b}$ & $4.90^{b}$ \\
\hline 25.0 & $0.72^{\mathrm{a}}$ & $1.65^{\mathrm{a}}$ & $1.65^{\mathrm{a}}$ & $1.64^{\mathrm{a}}$ & $5.66^{a}$ & $1.05^{b}$ & $1.52^{\mathrm{a}}$ & $1.40^{\mathrm{a}}$ & $1.52^{\mathrm{a}}$ & $5.49^{\mathrm{a}}$ \\
\hline 37.5 & $0.71^{\mathrm{a}}$ & $1.65^{\mathrm{a}}$ & $1.29^{c}$ & $1.50^{b}$ & $5.15^{b}$ & $1.05^{b}$ & $1.40^{\mathrm{b}}$ & $1.28^{b}$ & $1.28^{b}$ & $5.01^{b}$ \\
\hline LSD & 0.03 & 0.02 & 0.01 & 0.01 & 0.36 & 0.04 & 0.07 & 0.08 & 0.08 & 0.07 \\
\hline \multicolumn{11}{|l|}{ Variety } \\
\hline U-15 & $0.72^{\mathrm{a}}$ & $1.68^{\mathrm{a}}$ & $1.77^{\mathrm{a}}$ & $1.58^{\mathrm{a}}$ & $5.75^{\mathrm{a}}$ & $1.14^{\mathrm{a}}$ & $1.40^{\mathrm{a}}$ & $1.50^{\mathrm{a}}$ & $1.50^{\mathrm{a}}$ & $4.40^{\mathrm{a}}$ \\
\hline P-224 & $0.72^{\mathrm{a}}$ & $1.59^{b}$ & $1.33^{b}$ & $1.32^{\mathrm{C}}$ & $4.96^{c}$ & $1.14^{\mathrm{a}}$ & $1.30^{b}$ & $1.20^{b}$ & $1.40^{\mathrm{b}}$ & $3.90^{b}$ \\
\hline Ekalakala & $0.7^{\mathrm{b}}$ & $1.59^{b}$ & $1.24^{c}$ & $1.50^{b}$ & $5.03^{b}$ & $0.96^{b}$ & $1.30^{b}$ & $1.20^{b}$ & $1.00^{\mathrm{C}}$ & $3.50^{c}$ \\
\hline LSD & 0.01 & 0.05 & 0.08 & 0.06 & 0.30 & 0.04 & 0.06 & 0.07 & 0.07 & 0.27 \\
\hline CV\% & 1.60 & 1.00 & 1.00 & 21.10 & 5.40 & 4.10 & 5.40 & 6.60 & 6.20 & 5.70 \\
\hline
\end{tabular}
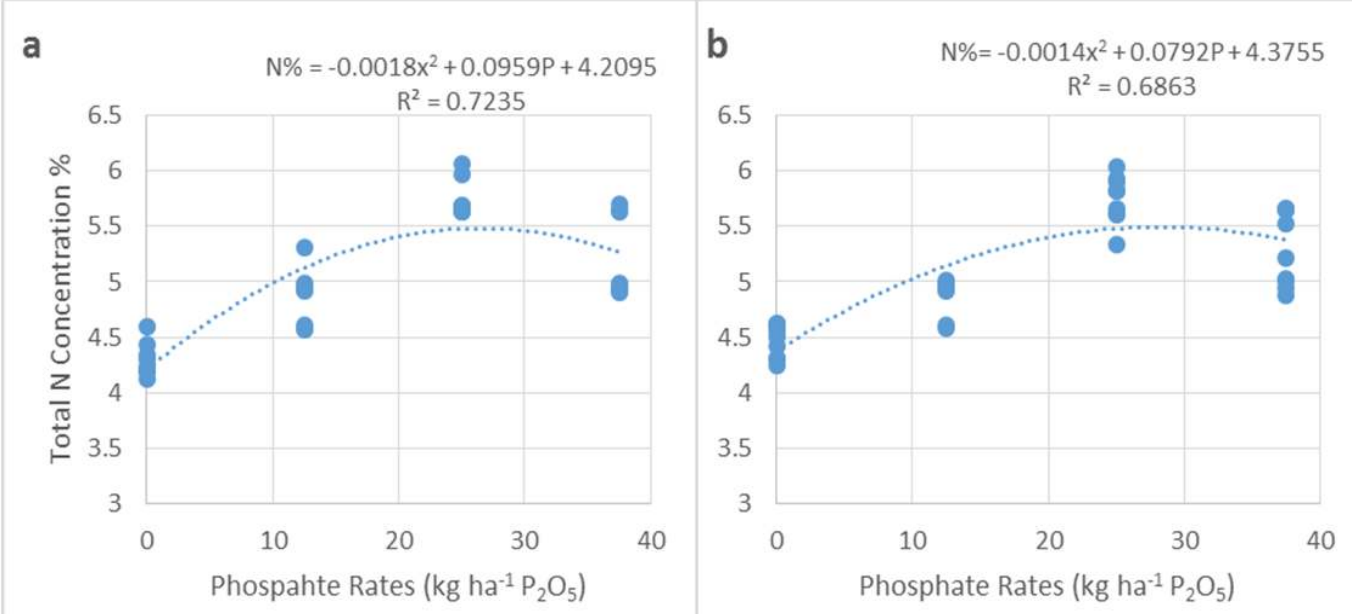

Fig. 1. The influence of phosphate rates on the total nitrogen concentration in finger millet plant for the short rains (a) and long rains (b) 


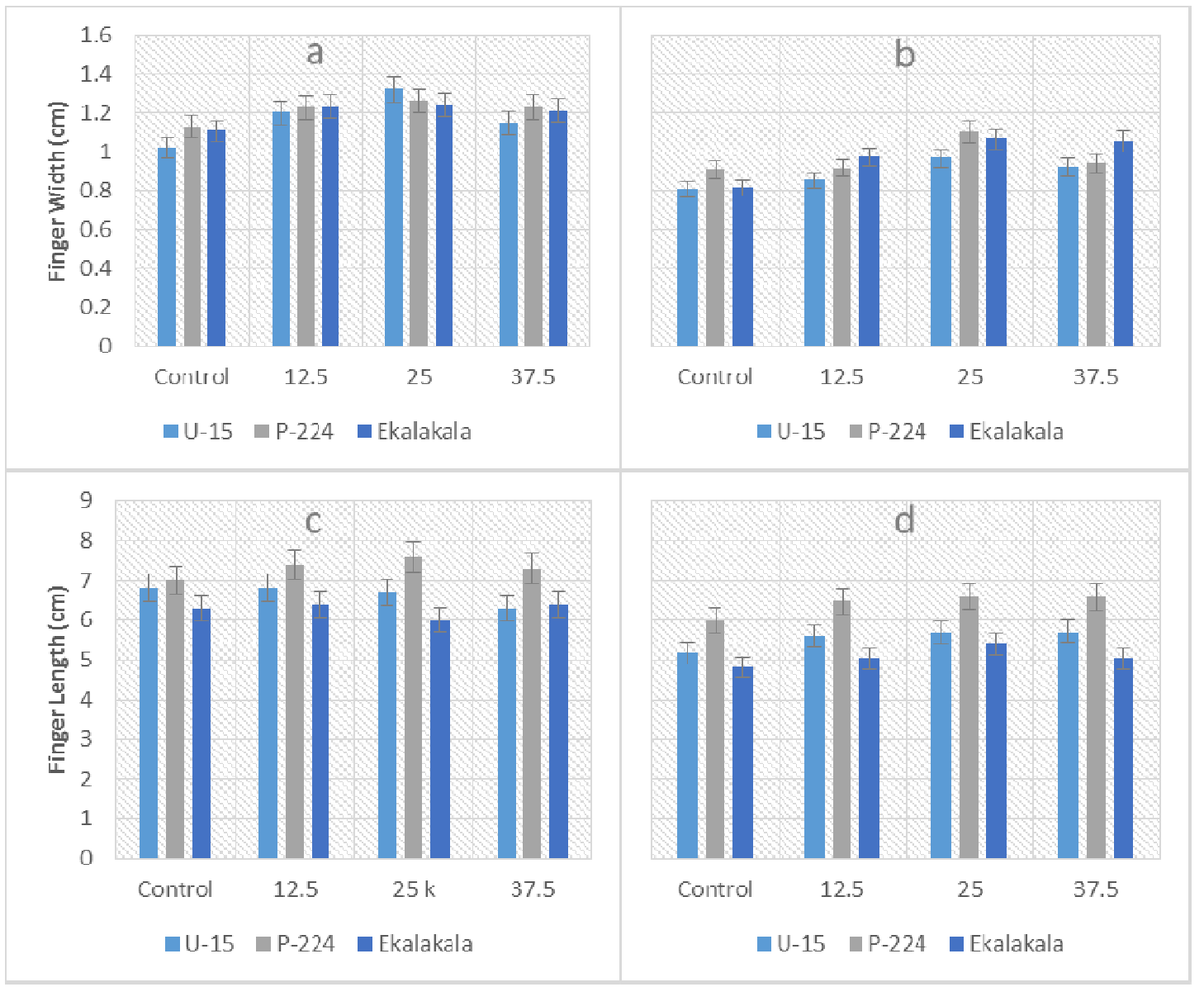

Fig. 2. Influence of phosphate rates on the finger width during the short (a) and long (b) rains season and finger length during the short (c) and long (d) rains seasons

Previous work based on multi location field experiments conducted in Eastern Uganda, Tenywa et al. [28] found that application of $P$ fertilizer $\left(20-40 \mathrm{~kg} \mathrm{P} \mathrm{P}_{2} \mathrm{O}_{5} \mathrm{ha}^{-1}\right)$ increased the growth and yield of finger millet compared to the no fertilizer control under row planting conditions. However, Hedge and Gowda [29] reported a reduction in finger millet grain yields from 16.3 to $14.7 \mathrm{~kg} \mathrm{ha}^{-1} \mathrm{P}_{2} \mathrm{O}_{5}$ when the $\mathrm{P}$ application rate was increased from 30 to $60 \mathrm{~kg} \mathrm{ha}^{-1} \mathrm{P}_{2} \mathrm{O}_{5}$. This could be due to negative interactions with micronutrients when applied beyond certain level (depending on soil characteristics). Similar to inorganic $\mathrm{N}$, this result suggests that application of excess $\mathrm{P}$ does not improve yield, but rather that application of balanced fertilizer is crucial.

The pattern in yields and yield components in response to $P$ supply is in line with findings reported by Sankar [30] in semi-arid Alfisols. There could be other limiting factors that could limit $P$ uptake and hence these yield components. Various other scientists $[31,32]$ also reported similar trends which are in agreement with our findings. They concluded that phosphorous had a significant impact on yield attributes of various cereals crops and the yield reduction after peak value a paradox in regards to some yield enhancing factors.

Notably, all the above traits were significantly influenced by varieties for both seasons as shown on Table 3. U-15 had the highest harvest index for both seasons but with the lowest number of grains per spikelet. Significant genotypic variation for traits related to $P$ acquisition and $P$ use efficiency has been observed in various crops. Cereal improvement in the recent decade has been mainly attributed to the increased harvest index. So far this trait has not been fully exploited in finger millet. Among the various factors influencing the 
harvest index, mineral nutrition is of utmost significance [33]. Reddy [34] on the effect of $P$ on stability of harvest index with two contrasting genotypes of finger millet contradicted this finding, he found that as $P$ level increased from 20 to $80 \mathrm{~kg} \mathrm{ha}^{-1}$ there was a significant increase in biomass and grain yield but the harvest index and partitioning percentage decreased significantly with increased $P$ levels. This contradiction was probably due to the difference in the available phosphorus values in the study soil and because of the rate where the highest in the study was more than double to that used in the current study.

U-15 and Ekalakala had the greatest threshing ability with the highest of $81.7 \%$ observed during the long rains season on U-15. The highest number of grains per spikelet was shown on P224 and Ekalakala. U-15 and Ekalakala had the highest number of panicles harvested and number of productive tillers on the net plot. The productive tillers accounted for almost $50 \%$ of the harvested panicles on U-15 and Ekalakala which directly impacted on the final grain yield. The superiority of $\mathrm{U}-15$ on most of the yield components translated to the highest yield among the varieties for both seasons as shown on Fig. 3. The short rains had a higher mean grain yield compared to the long rains where U15 revealed 3.41 and 1.94 tonnes per hectare respectively. The performance of U-15 probably indicates the predominance of additive gene effects in controlling these traits in the variety hence the high potential in yielding.

Matsuo et al. [35] also found significant differences in grain yield of rice varieties with variable $\mathrm{P}$ levels. Path coefficient analysis by Manyasa [36] revealed that productive tillers per plant, grains per spikelet and threshing percent had positive direct genetic effects on grain yield. The same results were also reported by Bezawelataw et al. [37].

Table 3. The effect of varieties on the harvest index, threshability, grains per spikelet, panicles and productive tillers during the long and short rains season

\begin{tabular}{|c|c|c|c|c|c|c|c|c|c|c|}
\hline \multirow[t]{2}{*}{ Variety } & \multicolumn{2}{|c|}{ Harvest index } & \multicolumn{2}{|c|}{ Threshing \% } & \multicolumn{2}{|c|}{$\begin{array}{c}\text { Grains/ } \\
\text { spikelet }\end{array}$} & \multicolumn{2}{|c|}{ Panicles $\left(3 \mathrm{~m}^{2}\right)$} & \multicolumn{2}{|c|}{$\begin{array}{l}\text { Productive } \\
\text { tillers }\left(3 \mathrm{~m}^{2}\right)\end{array}$} \\
\hline & $\begin{array}{l}\text { Short } \\
\text { rains }\end{array}$ & $\begin{array}{l}\text { Long } \\
\text { rains }\end{array}$ & $\begin{array}{l}\text { Short } \\
\text { rains }\end{array}$ & $\begin{array}{l}\text { Long } \\
\text { rains }\end{array}$ & $\begin{array}{l}\text { Short } \\
\text { rains }\end{array}$ & $\begin{array}{l}\text { Long } \\
\text { rains }\end{array}$ & $\begin{array}{l}\text { Short } \\
\text { rains }\end{array}$ & $\begin{array}{l}\text { Long } \\
\text { rains }\end{array}$ & $\begin{array}{l}\text { Short } \\
\text { rains }\end{array}$ & $\begin{array}{l}\text { Long } \\
\text { rains }\end{array}$ \\
\hline U-15 & $0.36^{a}$ & $0.41^{a}$ & $65.90^{a}$ & $81.70^{a}$ & $6.20^{\circ}$ & $6.10^{\mathrm{b}}$ & $270.20^{a}$ & $141.00^{\mathrm{ab}}$ & $125.00^{a}$ & $38.00^{a}$ \\
\hline P-224 & $0.31^{c}$ & $0.35^{\mathrm{c}}$ & $63.00^{\mathrm{b}}$ & $72.60^{\mathrm{b}}$ & $7.20^{\mathrm{a}}$ & $6.80^{a}$ & $238.90^{\mathrm{b}}$ & $123.00^{\mathrm{b}}$ & $107.00^{\mathrm{b}}$ & $19.00^{b}$ \\
\hline Ekalakala & $0.33^{\mathrm{b}}$ & $0.38^{\mathrm{b}}$ & $66.50^{\mathrm{a}}$ & $79.30^{\mathrm{a}}$ & $7.00^{\mathrm{a}}$ & $6.80^{a}$ & $246.40^{\mathrm{ab}}$ & $149.00^{\mathrm{a}}$ & $130.00^{\mathrm{a}}$ & $37.00^{\mathrm{a}}$ \\
\hline L.S.D & 0.02 & 0.02 & 2.09 & 3.11 & 0.45 & 0.58 & 25.37 & 19.70 & 13.09 & 6.60 \\
\hline CV (\%) & 11.50 & 7.80 & 7.40 & 4.70 & 7.90 & 10.20 & 11.90 & 25.50 & 19.80 & 7.40 \\
\hline
\end{tabular}

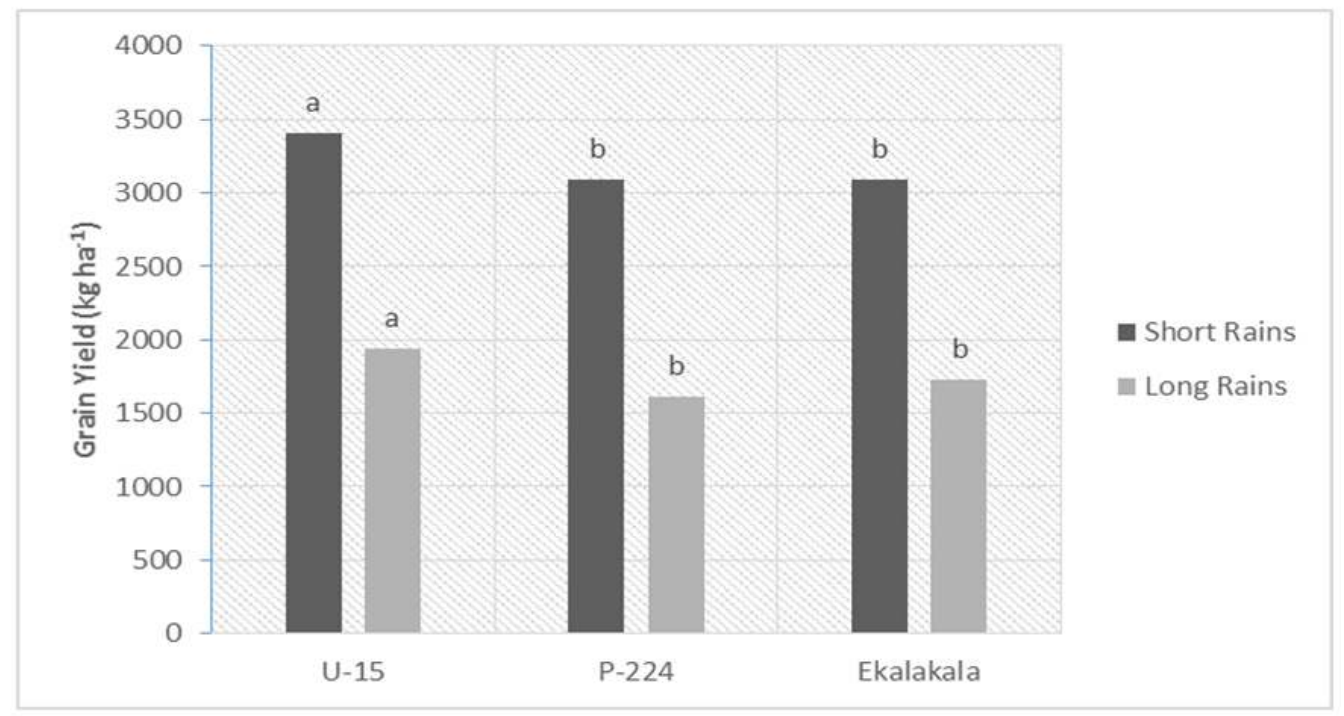

Fig. 3. Varietal effect on the grain yield during the short and long rains seasons 


\section{CONCLUSION}

Phosphorus had a positive influence on the nitrogen accumulation in the plant parts and total nitrogen uptake of finger millet as well as the finger width for both seasons with the peak observed at $25 \mathrm{~kg} \mathrm{ha}^{-1} \mathrm{P}_{2} \mathrm{O}_{5}$. The newly released variety $\mathrm{U}-15$ responded well to the low $\mathrm{N}$ in Makueni and yielded the highest $\left(3,410 \mathrm{~kg} \mathrm{ha}^{-1}\right)$ which is five times the national average production and is ideal to achieve food security, poverty eradication and economic growth which are topmost set targets for the sustainable development goals.

\section{ACKNOWLEDGEMENT}

Our gratitude to the entire ICRISAT staff in Nairobi, Kiboko and the casuals in the field who made this work possible and successful.

\section{COMPETING INTERESTS}

Authors have declared that no competing interests exist.

\section{REFERENCES}

1. Oduori CO. Small Millets Production and Research in Kenya. In: Riley, K.W., Gupta, S.C., Seetharam, A. and Mushonga, J.N. (eds). Advances in small millets. New Delhi: Oxford and IBH; 1993.

2. Consultative Group on International Agricultural Research. CGIAR Research: Areas of Research-Millet; 2001.

3. Takan JP, Muthumeenakshi S, Sreenivasaprasad B, Akello R. Bandyopadhyay R, Talbot NJ. Characterization of finger millet blast pathogen populations in East Africa and strategies for disease management; 2002.

4. Opala AP, Omami NO, Christopher J, Opile NR. Response of the African nightshade to phosphate fertilizer application in Western Kenya. Archive of Applied Science Research. 2013;5(1):195201.

5. LeBauer DS, Treseder KK. Nitrogen limitation of net primary productivity in terrestrial ecosystems is globally distributed. Ecology. 2008;89:371-379.

6. Elser JJ, Bracken MES, Cleland EE, Gruner DS, Harpole WS, Hillebrand $H$, Ngai JT, Seabloom EW, Shurin JB, Smith JE. Global analysis of nitrogen and phosphorus limitation of primary producers in freshwater, marine and terrestrial ecosystems. Ecol Lett. 2007;10:11351142.
7. Han W, Fang J, Guo D, Zhang Y. Leaf nitrogen and phosphorus stoichiometry across 753 terrestrial plant species in China. New Phytol. 2005;168:377-385.

8. Ordoñez JC, PMv B, Witte J-PM, Wright IJ, Reich PB, Aerts R. A global study of relationships between leaf traits, climate and soil measures of nutrient fertility. Glob Ecol Biogeogr. 2005;18:137-149.

9. Wright IJ, Reich PB, Cornelissen JHC, Falster DS, Garnier E, Hikosaka K, Lamont BB, Lee W, Oleksyn J, Osada N, Poorter $\mathrm{H}$, Villar $\mathrm{R}$, Warton DI, Westoby $\mathrm{M}$. Assessing the generality of global leaf trait relationships. New Phytol. 2005;166:485496.

10. Goron TL, Raizada MN. Genetic diversity and genomic resources available for the small millet crops to accelerate a new green revolution. Front. Plant Sci. 2015;6: 157.

11. Bhoite SV, Nimbalkar VS. Response of finger millet cultivars to nitrogen and phosphorus under rain-fed condition. J. Maharashtra Agric. Univ. 1996;20:189190.

12. Gupta N, Gupta AK, Gaur VS, Kumar A. Relationship of nitrogen use efficiency with the activities of enzymes involved in nitrogen uptake and assimilation of finger millet genotypes grown under different nitrogen inputs. Sci. World J. 2012;1-10.

13. CIMMYT. Kiboko Crops Research Station: A brief and visitors' guide: CIMMYT; 2013.

14. International Board for Plant Genetic Resources. Descriptors for Finger Millet. IBPGR Secretariat, Rome; 1985.

15. Okalebo JR, Gathua KW, Woomer PL. Laboratory methods of soil and plant analysis: A working manual. UNESCO, Nairobi, Kenya; 1993.

16. Ryan J, George E, Rashid A. Soil and Plant Analysis Laboratory Manual. Second edition. Jointly published by International Center for Agricultural Research in the dry areas (ICARDA) and the National Agricultural Research Centre (NARC), 2001;46-48.

17. Olsen DN, Sommers LE. Methods of soil analysis, part 2, chemical and microbiological properties. In: Page A.L., Miller, R.H. and Keeney, D.R. (Eds.). Agronomy monograph no. ( $2^{\text {nd }}$ edition). ASA, Madison, Wisconsin; 1982.

18. Yadav BK, Niwas R, Yadav RS, Tarafdar JC. Effect of Chaetomium globosum inoculation and organic matter on 
phosphorus mobilization in soil and yield of clusterbean. Annals of Arid Zone. 2009; 48(1):41-44.

19. Barbieri $P$, Echeverría HE, Saínz Rozas $\mathrm{HR}$, Andrade FH. Nitrogen use efficiency in maize as affected by nitrogen availability and row spacing. Agron. J. 2008;100: 1094-1100.

20. Li YF, Luo AC, Wei XH, Yao XG. Changes in phosphorus fractions, $\mathrm{pH}$ and phosphatase activity in rhizosphere of two rice genotypes. Pedosphere. 2008;18: 785-794.

21. Bowen GD, Rovira AD. The rhizosphere and its management to improve plant growth. Adv. Agron. 1999;66:1-102.

22. Wang $X$, Shen J, Liao $H$. Acquisition or utilization, which is more critical for enhancing phosphorus efficiency in modern crops? Plant Sci. 2010;179:302306.

23. Rose TJ, Wissuwa M. Rethinking internal phosphorus utilization efficiency. Advances in agronomy. Elsevier. 2012;185-217.

24. Mohidin $\mathrm{H}$, Hanafi MM, Rafii YM, Abdullah SNA, Idris AB, Man S, Idris J, Sahebi M. Determination of optimum levels of nitrogen, phosphorus and potassium of oil palm seedlings in solution culture. Bragantia, Campinas. 2015;74(3):247-254.

25. Ogembo JO. Effects of phosphorus deficiency on secondary metabolites and distribution of African Nightshade in Siaya and Kisii Counties, Kenya. MSc Dissertation, Kenyatta University; 2015.

26. Boyhan GE, Torrance RL, Hill CR. Effects of nitrogen, phosphorus, and potassium rates and fertilizer sources on yield and leaf nutrient status of short-day onions. HortScience. 2007;42(3):653-660.

27. Sankar GR, Sharma KL. Dhanapal GN, Shankar MA, Mishra PK, Venkateswarlu B, Grace JK. Influence of soil and fertilizer nutrients on sustainability of rainfed finger millet yield and soil fertility in semi-arid Alfisols. Commun. Soil Sci. Plant Anal. 2011;42:462-1483.

28. Tenywa JS, Nyende $P$, Kidoido $M$, Kasenge V, Oryokot J, Mbowa S. Prospects and constraints of finger millet production in Eastern Uganda. Afr. Crop Sci. J. 1999;7:569-583.

29. Hegde BR, Gowda L. Cropping systems and production technology for small millets in India. In Proceedings of the First International Small Millets Workshop, Bangalore, India, 29 October-2 November. 1986;209-236.

30. Bertrand I, Holloway RE, Armstrong RD, McLaughlin MJ. Chemical characteristics of phosphorus in alkaline soils from southern Australia. Australian Journal of Agricultural Research. 2003;41:61-76.

31. Glassop D, Smith SE, Smith FW. Cereal phosphate transporters associated with the mycorrhizal pathway of phosphate uptake into roots. Planta. 2005;222:688-698.

32. Rose TJ, Pariasca-Tanaka J, Rose MT. Genotypic variation in grain phosphorus concentration, and opportunities to improve P-use efficiency in rice. Field Crop Res. 2010;119:154-160.

33. Shankar AG, Udayakumar M, Prasad TG. Genotypic variability for net photosynthesis in finger millet (Eleusine coracana G.) genotypes: An approach to identity high CER types. Journal of Agronomy and Crop Science. 1990;165:240-252.

34. Reddy DVV, Udayakumar M, Prasad TG, Seethram A, Nanjareddy YA. Influence of NPK on relative stability of harvest index in finger millet. Karnataka J. Agric. Sci. 2004; 17(4):691-695.

35. Matsuo $T$, Kumazawa $K$, Ishii $R$, Ishihara $\mathrm{K}$, Hirata $\mathrm{H}$. Science of the rice plant Physiology. Tokyo: Food and Agricultural Policy Research Center. ISBN; 1996.

36. Manyasa EO. A study of the diversity, adaptation and gene effects for blast resistance and yield traits in East African finger millet (Eleusine coracana (L.) Gaertn) landraces. PhD Dissertation, University of KwaZulu-Natal; 2013.

37. Bezawelataw K, Sripichitt P, Wongyai W, Hongtrakul V. Genetic variation, heritability and path-analysis in Ethiopian finger millet (Eleusine coracana (L.) Gaertn) landraces. Kasetsart Journal (National Science). 2006;40:322-334.

(0) 2016 Wekha et al.; This is an Open Access article distributed under the terms of the Creative Commons Attribution License (http://creativecommons.org/licenses/by/4.0), which permits unrestricted use, distribution, and reproduction in any medium, provided the original work is properly cited.

Peer-review history:

The peer review history for this paper can be accessed here: http://sciencedomain.org/review-history/16885 